\title{
Current Status of Withania somnifera (L.) Dunal: An Endangered Medicinal Plant from Himalaya
}

\section{Sumaira Aslam¹, Naveed Iqbal Raja ${ }^{1}$, Mubashir Hussain ${ }^{1 *}$, Muhammad Iqbal' ${ }^{1}$, Muhammad Ejaz ${ }^{1}$, Danish Ashfaq², Hira Fatima3 ${ }^{3}$, Muhammad Ali Shah" ${ }^{4}$ Abd-Ur-Rehman1, Maria Ehsan'}

\author{
${ }^{1}$ Department of Botany, PMAS Arid Agriculture University, Rawalpindi, Pakistan \\ ${ }^{2}$ Department of Botany, University of Sargodha, Sargodha, Pakistan \\ ${ }^{3}$ Department of Biological Sciences, University of Lahore, Sargodha, Pakistan \\ ${ }^{4}$ Department of Biotechnology, University of Azad Jammu \& Kashmir, Muzaffarabad, Pakistan \\ Email: *mubashirhussain_22@hotmail.com
}

How to cite this paper: Aslam, S., Raja, N.I., Hussain, M., Iqbal, M., Ejaz, M., Ashfaq, D., Fatima, H., Shah, M.A., Abd-Ur-Rehman and Ehsan, M. (2017) Current Status of Withania somnifera (L.) Dunal: An Endangered Medicinal Plant from Himalaya. American Journal of Plant Sciences, 8, 1159-1169. https://doi.org/10.4236/ajps.2017.85076

Received: March 18, 2017

Accepted: April 27, 2017

Published: April 30, 2017

Copyright $\odot 2017$ by authors and Scientific Research Publishing Inc. This work is licensed under the Creative Commons Attribution International License (CC BY 4.0).

http://creativecommons.org/licenses/by/4.0/

\begin{abstract}
Withania somnifera is highly medicinal plant species of Pakistan floristically placed in the Western Himalayan Province, Himalaya Range of Azad Jammu and Kashmir and in the Soon valley (Salt Range) of Punjab Pakistan. It grows in high altitude of 5500 feet in the Himalayas. Its English name is Winter Cherry and its Urdu name is Asghand/Kutilal. It is the low lying shrub of about $1.50 \mathrm{~m}$ in height with erect branching. It grows in dry arid regions of Pakistan, India, China and Bangladesh. Its flowers are bisexual, small, axillary, greenish, solitary and few-flowered cymes. Chemical analysis of Ashwagandha showed that it has alkaloids and steroidal lactones (withanolides) as the main chemical constituent. W. somnifera has not yet been assessed for the IUCN Red List. However, in Pakistan, W. somnifera is falling under criteria A of endangered category. Asghand (W. somnifera) acquires much therapeutic potential which include sedative, narcotic, thyroid stimulation, anti-inflammatory, hypnotic, anti-stress, general tonic, diuretic, antimicrobial, and antitumor activities. There are number of threats responsible for the decrease of $W$. somnifera number in western Himalayan range and salt range of Punjab Pakistan which may include deforestation over exploitation and climatic changes. Conservation strategies need to be adopted for improving the population pool of $W$. somnifera. There is also the dire need to conserve this important medicinal plant species with some standard biotechnological approaches and conservation strategies in future.
\end{abstract}

\section{Keywords}

Withania somnifera, Endangered, Antimicrobial, Antitumor, Conservation 


\section{Introduction}

It is commonly recognized that the pace of plant extinction has been reached to one species per day as a consequence of anthropogenic activities and this decline rate is believed to be 1000 - 10,000 times faster than that would naturally occur [1] [2] and if this decline remains constant, 60,000 - 100,000 plant species may disappear in future [2] [3]. Major reason behind the current issue is the habitat loss by various anthropogenic activities, resulting in the fragmentation, alteration, and destruction of habitats. Furthermore, climate change is another major factor in this connection [4].

According to IUCN Red list, categories and criteria, unfortunately, insufficient work has been done on threatened plants of Pakistan and extremely little bit information is available on this subject [5]. The moist temperate in Himalaya regions of Pakistan acquires much attention for the conservation of environment as well as the sustainable use of all the natural resources. The decline in forest cover and significant changes in community structure are responsible for the decline of indigenous medicinal flora together with their traditional knowledge [6].

In the present study, distribution, morphology, chemical composition, medicinal properties, major threats, conservation status, and conservation strategies of the important endangered medicinal plant $W$. somnifera were discussed. Extensive grazing, deforestation and over-exploitation have caused forest degradation, habitat fragmentation and species extinction [7]. At high altitudes of $\mathrm{Hi}$ malaya where possible availability of cultivated land is fairly less, so development of botanical gardens as well as promotion of kitchen garden or home gardens may be regarded as the conservation strategy for sustainable utilization of medicinal plants. The people of the native area mainly rely on the plant diversity for numerous purposes and ultimately lead plants to extinction [8]. Damages to the plants are smuggling of trees and shrubs; careless and illicit cutting and overgrazing, loss of habitat, converting the plan slopes in the forests for cultivation purposes also put forth vast stress on the vegetation and these results in degradation to the environment [9] [10].

\section{Distribution of W. somnifera}

W. somnifera (Dunal) is member of family Solanaceae. Its English name is Winter Cherry and its Urdu name is Asghand/Kutilal [6]. This plant is xerophytic in nature, distributed in the drier parts of Pakistan, Afghanistan, India, Sri Lanka, and in the Mediterranean regions as shown in Figure 1. In Pakistan, it is found in Nandiar Khuwar, District Battagram of Western Himalayan Province [6] and in regions of Azad Jammu and Kashmir [11]. W. somnifera is also associated with Knotti Garden sites of Soon valley and Anga, Khabeki and (Salt Range) of Punjab Pakistan [12] [13] [14].

\section{Habitat}

The plant is distributed in dry areas of sub-tropics and is low lying shrub of $1.50 \mathrm{~m}$ height possessed erect branching. It also grows in dry arid areas of India, Pakistan, 


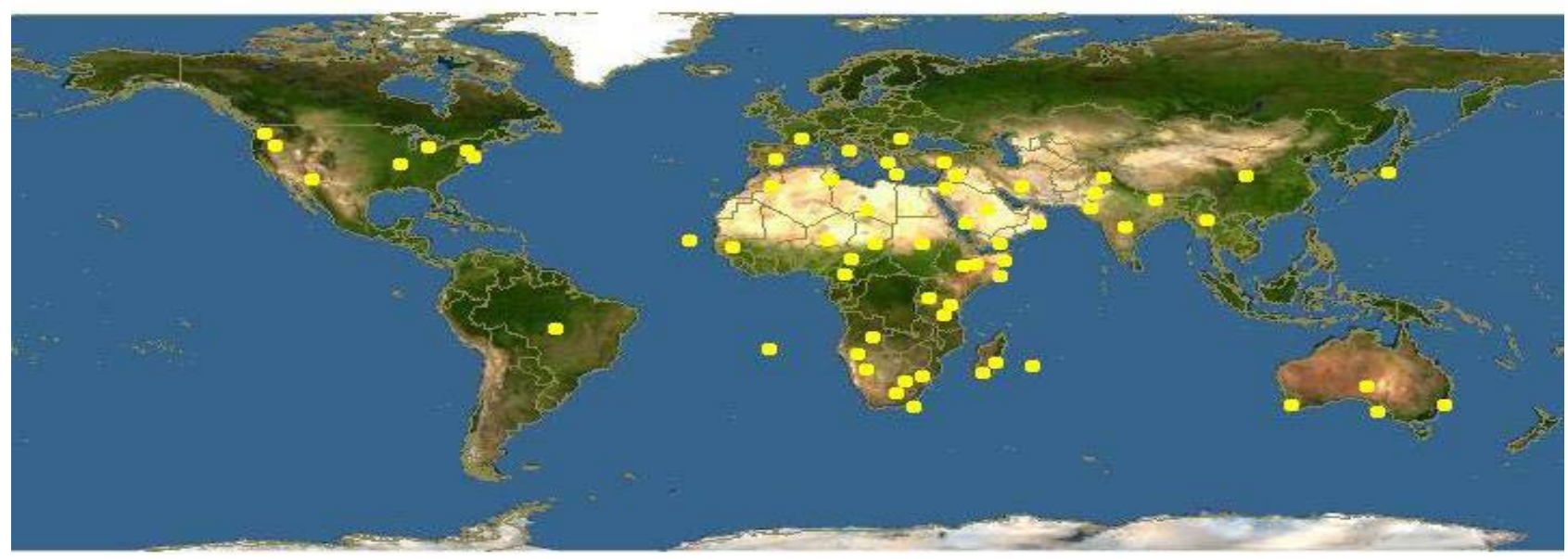

Figure 1. Distribution of $W$. somnifera (Yellow dots are showing plant distribution).

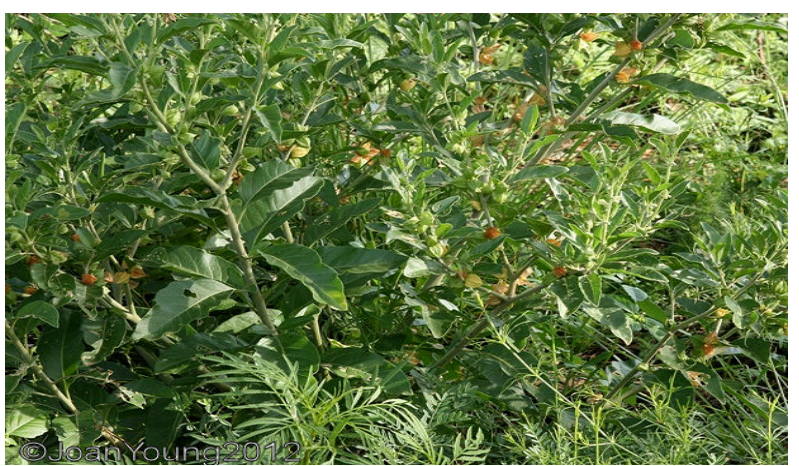

(a)

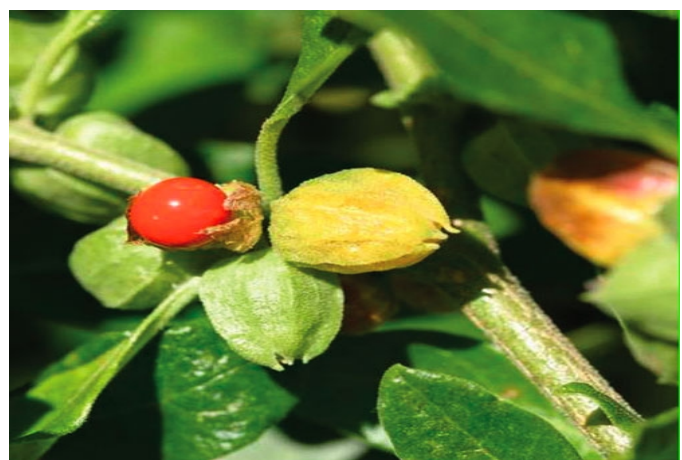

(b)

Figure 2. (a) W. somnifera plant; (b) W. somnifera fruits.

China and Bangladesh. It is distributed in the base of hills in broad-leaved and Pinus roxburghii forests [6].

\section{Morphological Description}

W. somnifera Dunal (Synon. Physalis flexuosa L.; Physalis somnifera L). is an erect, stellate-tomentose, grayish, under shrub with $30-75 \mathrm{~cm}$ in height having long tuberous roots (Figure 2(a)). Leaves are sub-opposite, broadly ovate to oblong, alternate, petiolate, entire and sub-acute with lamina $(5-10 \times 2.5-7) \mathrm{cm}$. Flowers are bisexual, greenish, small, solitary, axillary, or in few-flowered cymes. The calyx is gamosepalous possesses five $3-5 \mathrm{~mm}$ lobes, inflated and acrescent in a fruit. The corolla is greenish-yellow of five $5-8 \mathrm{~mm}$ lobes and campanulate. Stamens are five numbers. The ovary is glabrous, globose and ovoid containing many ovules. The filiform style as well as 2-lobed stigma, fruit is a globose/berry, orange-red in color when ripen and covered in the enlarged calyx (Figure 2(b)). Seeds are many, discoid, yellow and reniform [15] [16] [17].

\section{Chemical Constituents}

Chemical analysis of Ashwagandha showed that it has alkaloids and steroidal lactones (withanolides) as its main constituents (Figures 3(a)-(c)). Several si- 


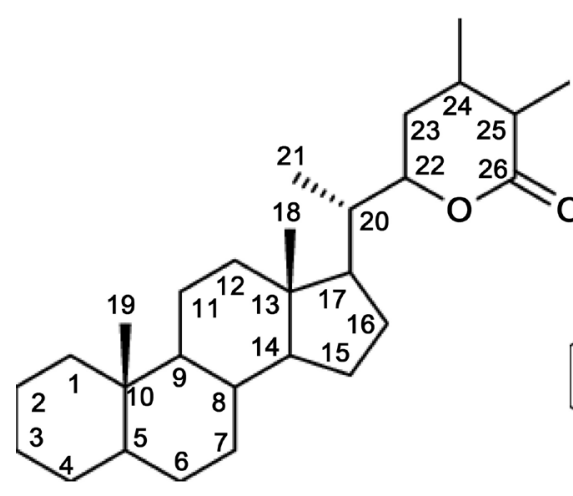

(a)

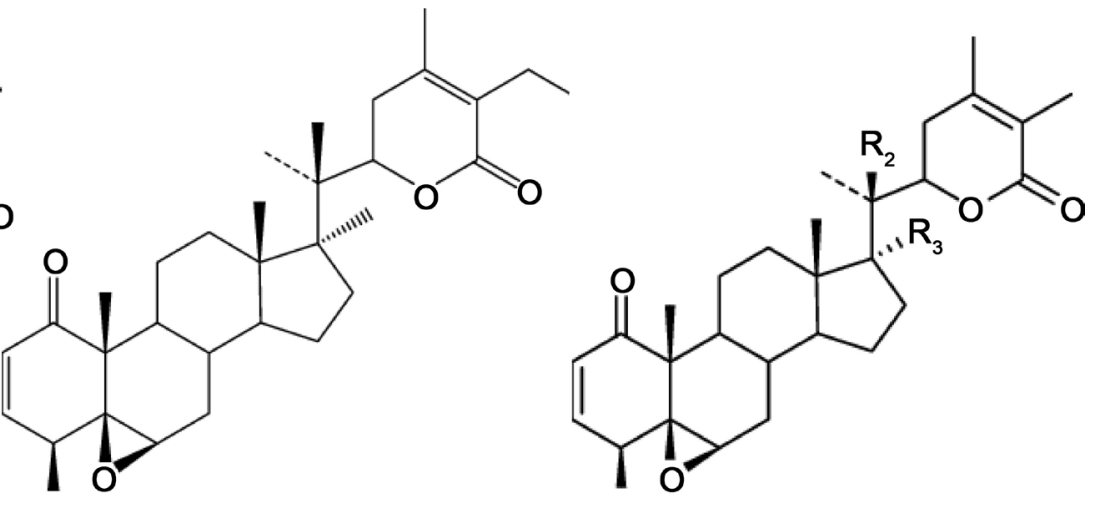

(b)

(c)

Figure 3. The basic structure of (a) Withanolide (b) Withaferin A and (c) Withanolide A [18].

toindosides, thirty five withanolides and twelve alkaloids from $W$. somnifera plant have been isolated and well-studied. Among all these withanine is the major constituent. The withanolides contains C-28 steroidal nucleus along with C-9 side chain and with a six membered lactone ring [19]. Significant Ashwaganda's pharmacological activity has been characterized by the two main withanolides, withaferin A and withanolide D. More chemical analysis has showed the presence of Alkaloids like Anaferine, Anahygrine, Beta-Sisterol, Chlorogenic acid (found in leaf only), Cysteine (found in fruit), Iron, Cuscohygrine, Pseudotropine, Somniferinine, Scopoletin, Tropanol, Somniferiene, Withananine, Withanine and Withanolides A-Y Steroidal lactones [20] [21].

\section{Importance of $W$. somnifera}

\subsection{Source of Fuel and Fodder}

The local people use this plant species as source of fuel, for cooking and heating during winter as they lack the natural gas facility. It is also widely used as a fodder plant [11].

\subsection{Medicinal Uses}

Medicinal plants are nature gift for humanity to treat various human ailments. Among them, $W$. somnifera possess various biological properties. W. somnifera possess high anti-inflammatory activity [22]. Anti-inflammatory activity has been associated due to biologically active steroids. Withaferin A is a chief component of those steroids. Its effectiveness is comparable to hydrocortisone sodium succinate dose [23]. The potential chemical constituents of $W$. somnifera are effective against pathogenic bacteria, fungi and viruses [23] [24]. Asghand revealed a considerable modulation of immune reactivity in model animals. Withanolide E specifically affect on T lymphocytes only while Withaferin A potentially affects both B as well as T lymphocytes [25] [26] [27] [28]. Various studies demonstrated ashwagandha proved to be effective in treatment of osteoarthritis [29], inflammation [30] [31] [32] as well as tardive dyskinesia [33]. Studies also showed ashwagandha to be a potent antimicrobial agent, along with antifungal 
activity [34] [35] and moderate antibacterial activity against Pseudomonas aeruginosa and Staphyloccus aureus [36]. Ashwagandha also revealed an antidepressant effect analogous to that persuaded by imipramine in forced swim-induced "learned helplessness" and "behavioral despair" tests. Other parallel studies validate these results, lending support to the utilization of ashwagandha as a potent anti-stress adaptogen [37] [38]. W. somnifera though possess an advantage over Panax ginseng because it does not results in ginseng-abuse syndrome, a condition recognized by insomnia, high blood pressure, water retention and muscle tension [39]. W. somnifera may also enhance thyroid activity ultimately effects on cellular antioxidant systems. These results specify ashwaganda as a valuable plant in treatment of hypothyroidism [40]. Hypo-cholesterolemic, hypoglycemic, and diuretic effects of ashwagandha roots were evaluated in human subjects. Considerable increases in urine volume, urine sodium, decreases in serum cholesterol as well as triglycerides and low-density lipoproteins were moreover seen [41]. Ashwagandha revealed stimulatory effects, both in vitro in addition to in vivo on the production of cytotoxic $\mathrm{T}$ lymphocytes and depicted the potential to suppress tumor growth [42]. The chemo-preventive activity of plant is owing to the antioxidant or free radical scavenging action of the extract [43].

\section{Conservation Status}

W. somnifera has not yet been assessed for the IUCN Red List. However, Siddique et al. [44] and Sharma et al. [45] declared W. somnifera as endangered and rare plant. In Pakistan, W. somnifera is falling in criteria A of endangered category [6]. So there is need to conserve this species like highly medicinal wild plant species [46] and economically important plants Citrus reticulata [47].

\section{Threats towards Extinction of W. somnifera}

The various threats are facing by $W$. somnifera which leads towards the extinction of this highly medicinal species. Increase in human population and constant unplanned over exploitation of this plant for medicinal, firewood and fodder purposes has resulted damage into the Withania species.

\subsection{Deforestation}

Deforestation in the salt valley and Himalayas is mainly due to the demographic pressure and many further related effects like livestock population increase in demand of land for cultivation, and utilization of the forests to meet growing needs for fuel as well as fodder. Conversely, social issues such as perceptions, social relationships together with the natural resources as seen by various social groups, concerns of access to as well as control over natural resources, and matters of power relative to deforestation, have hardly ever been discussed in literature as probable driving forces to deforestation.

\subsection{Improper Collection and over Exploitation}

In Pakistan medicinal plants are mostly collected from the wild areas. Unfortu- 
nately local collectors are unaware about the best plant collection procedures. It was observed that commercial gatherers collect medicinal plants in large amounts from remote areas of the Himalayan range. This activity is likely grounds in rapid depletion of medicinal plant resources in the area. Similar activities have been reported in other areas such as Swat [48] whereas Choudhry et al. [49] reported that five hundred local families are engaged in medicinal plant collection and that they annually collected 5000 tons of medicinal plants. Same is the case with $W$. somnifera and its population size has been lessened up to $67 \%$ owing to loss of habitat by local people and its improper medicinal collection [6].

\subsection{Climatic Changes}

During last many years, less rain fall and large scale deforestation in the Himalayan range has rigorously changed the environment owing to which lush green slopes have been transformed to barren land [12]. Similar to global warming, this is causing progressive rise in temperature resulting in loss of many important medicinal plants such as Withania species [50].

\section{Conservation Strategies}

W. somnifera is a highly important medicinal plant and used globally in pharmaceutical industry. Withania propagates vegetative in its natural state, but this propagation rate is much slow to meet demand of high quality planting material for commercial cultivation [51]. The $W$. somnifera plant is a set and valuable resource that requires wise, efficient as well as sustainable management and conservation strategies. Therefore, instant conservation measures as projected below are immediately necessary in order to protect the plant from extinction. The conservation strategies should be adopted for the conservation of highly medicinal plants [52] [53].

Biotechnological techniques can help us to conserve this miracle plant. A swift and extremely effective method is the micropropagation method for elite selection of Withania by auxiliary branching method utilizing shoot tip as explants was standardized by [51]. Shoot cultures were initiated on MS medium containing BA $(0.5-2.0 \mathrm{mg} / \mathrm{L})$ with NAA $(0.2-0.5 \mathrm{mg} / \mathrm{L})$ containing $3 \%$ commercial sucrose and $0.8 \%$ agar. This fast and competent regeneration protocol could be used for large production of selected cultivated varieties at commercial scale. This direct regeneration method which lessens genetic flux that is normally come across during callus mediated regeneration will assist in production of large number of selected superior chemo types ashwagandha which has highquality demand in the present drug market. Iqbal et al. [54] established a protocol for synthetic seed production by using artificial coating material (sodium alginate) and complexing agent (calcium chloride) through somatic embryogenesis. This synthetic seed technology can also be very helpful for medicinal plants such as Withania species. Siddique et al. [44] have reported an easy and efficient protocol for micropropogation of the endangered medicinal plant $W$. somnifera. 
This protocol can be used for booming and rapid technique that can be utilized for ex-situ conservation. The implementation of these protocols can aid to diminish the pressure on wild populations and contribute toward the conservation of the valuable plant $W$. somnifera.

It is anticipated that a standard protocol to persuade multiple shoots in cultures may offer more homogenous source of this important medicinal plant. Similarly a mass awareness campaign must be launched on both governmental as well as community level in order to endorse consciousness among the people about the importance of plants and conservation of the flora. Moreover, proper documentation and conservation of indigenous knowledge requires to be done. Appropriate training of the local communities regarding the conservation and sustainable use of flora needs to be given. Anthropogenic impacts like deforestation and overgrazing should be reduced. These species should also be grown in botanical gardens. Permanent monitoring programs should be developed. So there is the urgent need to conserve this plant species like other threatened plant species [55] [56] [57] [58] [59].

\section{Conclusion}

From the above discussion, it can be concluded that low rain fall, over grazing, population pressure, natural and accidental fires, soil aridity, deforestation, and over exploitation of medicinal plants are the major threats to biodiversity in the Himalayan and salt range. If the local people were not provided exchange of these problems, then the triumphing disturbances will rapidly eliminate the remaining patches of vegetation, predominantly medicinal flora of this biodiversity, rich areas including $W$. somnifera. This review has been compiled to highlight ample information about the status of W. somnifera, major threats to Himalayan biodiversity and conservation strategies to maintain population of important medicinal plants such as W. somnifera. Instantaneous and complete protection, effective community participation, efficient recovery system and biotechnological approaches for long term conservation are essential for sustainable use of $W$. somnifera in future.

\section{Conflict of Interest Statement}

We declare that we have no conflict of interest.

\section{References}

[1] Hilton-Taylor, C. (2000) IUCN Red List of Threatened Species. IUCN, Gland, Switzerland and Cambridge, UK.

[2] Akeroyd, J. (2002) A Rational Look at Extinction. Plant Talk, 28, 35-37.

[3] Bramwell, D. (2002) How Many Plant Species Are There? Plant Talk, 28, 32-34.

[4] Thomas, C.D., Gameron, A., Green, R.E., Bakkenes, M., Beaumont, L.J., Collingham, Y.C., Erasmus, B.F.N., Siqueira, M.F., Grainger, A., Hannah, L., Hughes, L., Huntley, B., Jaarsveld, A.S., Midgley, G.F., Miles, L., Ortega-Huerta, M.A., Peterson, A.T., Phillips, O.L. and William, S.E. (2004) Extinction Risk from Climate Change. Nature, 427, 145-148. https://doi.org/10.1038/nature02121 
[5] Alam, J. and Ali, S.L. (2009) Conservation Status of Astraglus gilgitensis Ali (Fabaceae): A Critically Endangered Species in Gilgit District, Pakistan. Phyton, 48, 211 223.

[6] Haq, F. (2011) Conservation Status of the Critically Endangered and Endangered Species in the Nandiar Khuwar Catchment District Battagram, Pakistan. International journal of Biology and Conservation, 3, 27-35.

[7] Sala, O.E., Chapin, F.S., Armesto, J.J., Berlow, E., Bloomfield, J., Dirzo, R., HuberSanwald, E., Huenneke, L.F., Lackson, R.B., Kinzing, A., Leemand, R., Lodge, D.M., Mooney, H.A., Oesterheld, M., Poff, N.L., Sykes, M.T., Walker, B.H., Walker, M. and Wall, D.H. (2010) Global Biodiversity Scenarios for the Year 2010. Science, 287, 1770-1774. https://doi.org/10.1126/science.287.5459.1770

[8] Ahmad, H., Alam, M. and Haq, F. (2010) Species Diversity and Conservation Status of the Diversity of Vascular Plants of Nandiar Khuwar District Battagram, Pakistan: Workshop on International Symposium on Biology of Rare and Endemic Plant Species. Biorare Symposium, Fethiye-Mugla, Turkey, 26-29 May 2010, 45.

[9] Muhammad, S. (2003) Resource Management Plan. Hillan-Battagram Forests, Azad Kashmir, Pakistan, 1-32.

[10] Haq, F., Ahmad, H. and Alam, M. (2010) M. Phil. Thesis on Species Diversity of Vascular Plants of Nandiar Khuwar Battagram.

[11] Bano, A., Ayub, M., Rashid, S., Sultana, S. and Sadia, H. (2013) Ethnobotany and Conservation Status of Floral Diversity of Himalayan Range of Azad Jammu and Kashmir-Pakistan. Pakistan Journal of Botany, 45, 243-251.

[12] Ahmad, I., Hussain, M., Rehman, A., Mustafa, I., Farooq, M., Jabeen, S. and Zafar, S. (2012) Threats to Medicinal Plant Diversity in Soon Valley (Salt Range) of Punjab, Pakistan. International Researcher, 4, 157-165.

[13] Nawaz, S., Hameed, M., Ashraf, M., Ahmad, F., Ahmad, M.S.A., Hussain, M., Ahmad, I., Younis, A. and Ahmad, K.S. (2012) Diversity and Conservation Status of Economically Important Flora of the Salt Range, Pakistan. Pakistan Journal of Bota$n y, 44,203-211$.

[14] Uddin, Q., Samiulla, L., Singh, V.K. and Jamil, S.S. (2012) Phytochemical and Pharmacological Profile of Withania somnifera Dunal: A REVIEW. Journal of Applied Pharmaceutical Science, 2, 170-175.

[15] Schonbeck-Temesy, E. (1972) In: Iranica, F. and Rechinger, K.H., Eds., Akademische Druck- $u$, Verlagsanstalt, Graz, Austria, 100, 29-26.

[16] Hepper, F.N. (1991) In: Hawkes, J.G., Lester, R.N., Nee, M. and Estrada, E., Eds., Solanaceae III: Taxonomy, Chemistry, Evolution, Royal Botanic Gardens, Kew, UK, 211-227.

[17] Mozaffarian, V. (2003) Trees and Shrubs of Iran. Farhange Moaser, Tehran, Iran, 874-877.

[18] Mirjalili, M.H., Moyano, E., Bonfill, M., Cusido, R.M. and Palazon, J. (2009) Steroidal Lactones from Withania somnifera, an Ancient Plant for Novel Medicine. Molecules, 14, 2373-2393. https://doi.org/10.3390/molecules14072373

[19] Padmawar, A. (2001) Withania somnifera. Monograph for Anruta Herbals, Ltd.

[20] Bone, K. (1996) Clinical Applications of Ayurvedic and Chinese Herbs. Phytotherapy Press, Queensland, Australia, 13, 7-41.

[21] Elsakka, M., Grigorescu, E. and Stanescu, U. (1990) Review of Medical Children. Society of Medical Naturalists Lasi, 94, 385-387.

[22] Anabalagan, K. and Sadique, J. (1985) Withania somnifera (Ashwagandha), a Rejuvenating Herbal Drug Which Controls Alpha-2-Macroglobulin Synthesis during In- 
flammation. International Journal of Crude Drug Research, 23, 177-183. https://doi.org/10.3109/13880208509069028

[23] Khare, C.P. (2007) Indian Medicinal Plants-An Illustrated Dictionary. First Indian Reprint, Springer (India) Pvt. Ltd., New Delhi, 717-718.

[24] Rastogi, R.P. and Mehrotra, B.N. (1998) Compendium of Indian Medicinal Plants. 2nd Reprint, Central Drug Research Institute, Lucknow and National Institute of Science Communication, Council of Scientific and Industrial Research, New Delhi, 434-436.

[25] Aggarwal, R., Diwanay, S., Patki, P. and Patwardhan, B. (1999) Studies on Immunomodulatory Activity of Withania somnifera (Ashwagandha) Extracts in Experimental Immune Inflammation. Journal of Ethnopharmacology, 67, 27-35. https://doi.org/10.1016/S0378-8741(99)00065-3

[26] Davis, L. and Kuttan, G. (2000) Immunomodulatory Activity of Withania somnifera. Journal of Ethnopharmacology, 71, 193-200. https://doi.org/10.1016/S0378-8741(99)00206-8

[27] Gautam, M., et al. (2004) Immune Response Modulation to DPT Vaccine by Aqueous Extract of Withania somnifera in Experimental System. International Immunopharmacology, 4, 841-849. https://doi.org/10.1016/j.intimp.2004.03.005

[28] Rasool, M. and Varalakshmi, P. (2006) Immunomodulatory Role of Withania somnifera Root Powder on Experimental Induced Inflammation: An in Vivo and in Vitro Study. Vascular Pharmacology, 44, 406-410. https://doi.org/10.1016/j.vph.2006.01.015

[29] Kulkarni, R.R., Patki, P.S., Jog, V.P., et al. (1991) Treatment of Osteoarthritis with a Herbomineral Formulation: A Double-Blind, Placebo-Controlled, Cross-Over Study. Journal of Ethnopharmacology, 33, 91-95. https://doi.org/10.1016/0378-8741(91)90167-C

[30] Angalagan, K. and Sadique, J. (1981) Influence of an Indian Medicine (Ashwagandha) on Acute-Phase Reactants in Inflammation. Indian Journal of Experimental Biology, 19, 245-249.

[31] Begum, V.H. and Sadique, J. (1988) Long-Term Effect of Herbal Drug Withania somnifera on Adjuvant-Induced Arthritis in Rats. Indian Journal of Experimental Biology, 26, 877-882.

[32] Chaudhary, G., Sharma, U., Jagannathan, N. and Gupta, Y. (2003) Evaluation of Withania somnifera in a Middle Cerebral Artery Occlusion Model of Stroke in Rats. Clinical Experimental Pharmacology and Physiology, 30, 399-404. https://doi.org/10.1046/j.1440-1681.2003.03849.x

[33] Bhattacharya, S.K., Bhattacharya, D., Sairam, K. and Ghosal, S. (2002) Effect of Withania somnifera Glycowithanolides on a Rat Model of Tardive Dyskinesia. Phytomedicine, 9, 167-170. https://doi.org/10.1078/0944-7113-00089

[34] Abou-Douh, A.M. (2002) New Withanolides and Other Constituents from the Fruit of Withania somnifera. Architectural Pharmacology, 335, 267-276. https://doi.org/10.1002/1521-4184(200208)335:6<267::AID-ARDP267>3.0.CO;2-E

[35] Choudhary, M.I., Dur-e-Shahwar, Parveen, Z., et al. (1995) Antifungal Steroidal Lactones from Withania coagulance. Phytochemistry, 40, 1243-1246. https://doi.org/10.1016/0031-9422(95)00429-B

[36] Ali, N.A., Julicch, W.D., Kusnick, C. and Lindequist, U. (2001) Screening of Yemeni Medicinal Plants for Antibacterial and Cytotoxic Activities. Journal of Ethnopharmacology, 74, 173-179. https://doi.org/10.1016/S0378-8741(00)00364-0

[37] Bhattacharya, A., Ghosal, S. and Bhattacharya, S.K. (2001) Anti-Oxidant Effect of Withania somnifera Glycowithanolides in Chronic Foot Shock Stress Induced Per- 
turbations of Oxidative Free Radical Scavenging Enzymes and Lipid Peroxidation in Rat Frontal Cortex and Striatum. Journal of Ethnopharmacology, 74, 1-6. https://doi.org/10.1016/S0378-8741(00)00309-3

[38] Dhuley, J.N. (2000) RETRACTED: Adaptogenic and Cardioprotective Action of Ashwagandha in Rats and Frogs. Journal of Ethnopharmacology, 70, 57-63. https://doi.org/10.1016/S0378-8741(99)00177-4

[39] Andallu, B. and Radhika, B. (2000) Hypoglycemic, Diuretic and Hypocholesterolemic Effect of Winter Cherry (Withania somnifera) Root. Indian Journal of Experimental Biology, 38, 607-609.

[40] Panda, S. and Kar, A. (1999) Withania somnifera and Bauhinia pupurea in the Regulation of Circulating Thyroid Hormone Concentrations in Female Mice. Journal of Ethnopharmacology, 67, 233-239. https://doi.org/10.1016/S0378-8741(99)00018-5

[41] Bhattarcharya, S.K. and Muruganandam, A.V. (2003) Adaptogenic Activity of Withania somnifera: An Experimental Study Using a Rat Model of Chronic Stress. Pharmacology Biochemistry and Behavior, 75, 547-555. https://doi.org/10.1016/S0091-3057(03)00110-2

[42] Davis, L. and Kuttan, G. (2002) Effect of Withania somnifera on CTL Activity. Journal of Experimental and Clinical Cancer Research, 21, 115-118.

[43] Prakash, J., Gupta, S.K. and Dinda, A.K. (2002) Withania somnifera Root Extract Prevents DMBA-Induced Squamous Cell Carcinoma of Skin in Swiss Albino Mice. Nutrition and Cancer, 42, 91-97. https://doi.org/10.1207/S15327914NC421_12

[44] Siddique, N.A., Bari, M.A., Sharmin, S., Rehman, M.H., Hassan, M.R., Khan, M.S.I. and Islam, M.S. (2004) Plant Regeneration of Withania somnifera (L.) Dunal (Ashwagandha) from Nodal Segments Derived Callus an Endangered Medicinal Plant in Bangladesh. Journal of Biological Sciences, 4, 219-223. https://doi.org/10.3923/jbs.2004.219.223

[45] Sharma, N., Sharma, M.D., Dhiman, M. and Koshy, E.P. (2014) Micropropagation Strategies for Conservation of Endangered Medicinal plant Withania somnifera (L.) Dunal. Journal of Cell Tissue Research, 14, 43-33.

[46] Iftikhar, A., Qureshi, R., Munir, M., Shabbir, G., Hussain, M. and Khan, M.A. (2015) In Vitro Micropropagation of Solanum villosum-A Potential Alternative Food Plant. Pakistan Journal of Botany, 47, 1495-1500.

[47] Hussain, M., Raja, N.I., Iqbal, M., Iftikhar, A., Sadaf, H.M., Sabir, S., Sultan, M.A. and Faz, M.N.A. (2016) Plantlets Regeneration via Somatic Embryogenesis from the Nucellus Tissues of Kinnow Mandarin (Citrus reticulata L.). American Journal of Plant Sciences, 7, 798-805. https://doi.org/10.4236/ajps.2016.76074

[48] Sarwat, Shinwari, Z.K. and Ahmad, N. (2012) Screening of Potential Medicinal Plants from District Swat Specific for Controlling Women Diseases. Pakistan Journal of Botany, 44, 1193-1198.

[49] Choudhry, M., Ahmad, S., Ali, A., Sher, H. and Malik, S. (2000) Market Study of Medicinal Herbs in Malakand Peshawar, Lahore and Karachi. Technical Report, Swiss Agency for Development and Cooperation (SDC), Inter Cooperation, Peshawar.

[50] Ahmad, H., Ahmad, A. and Jan, M.M. (2002) The Medicinal Plants of Salt Range. Online Journal of Biological Sciences, 2, 175-177.

https://doi.org/10.3923/jbs.2002.175.177

[51] Ahmad Baba, I., Alia, A., Saxena, R.C., Itoo, A., Kumar, S. and Ahmad, M. (2013) International Journal of Pharmaceutical Science Invention, 2, 6-11.

[52] Hussain, M., Raja, N.I., Akram, A., Iftikhar, A., Ashfaq, D., et al. (2017) A Status 
Review on the Pharmacological Implications of Artemisia absinthium: A Critically Endangered Plant. Asian Pacific Journal of Tropical Disease, 7, 185-192. https://doi.org/10.12980/apjtd.7.2017D6-385

[53] Tahir, N., Bibi, Y., Iqbal, M., Hussain, M., et al. (2016) Overview of Dioscorea deltoidea Wall. Ex Griseb: An Endangered Medicinal Plant from Himalaya Region. Journal of Biodiversity and Environmental Science, 9, 13-24.

[54] Iqbal, M., Ali, A., Naveed, N.H., Khan, U.A., Faz, M.N.A., Imran, M., Ashfaq, D. and Hussain, M. (2016) Effect of Explants and Growth Regulators on the Expression of Callogenesis, Somatic Embryogenesis and Plantlets Formation in Sugarcane (Saccharum officinarum L.). International Journal of Biosciences, 9, 147-156. https://doi.org/10.12692/ijb/9.4.147-156

[55] Hussain, M., Bibi, Y., Raja, N.I., Iqbal, M., Aslam, S., Tahir, N., Imran, M. and Iftikhar, A. (2016) A Review of Therapeutic Potential of Ajuga bracteosa: A Critically Endangered Plant from Himalaya. Journal of Coastal Life Medicine, 4, 918-924. https://doi.org/10.12980/jclm.4.2016J6-163

[56] Sabir, S., Arshad, M., Hussain, M., Sadaf, H.M., Sohail, Imran, M., Yasmeen, F., Saboon, and Chaudhari, S.K. (2016) A Probe into Biochemical Potential of Aconitum violaceum: A Medicinal Plant from Himalaya. Asian Pacific Journal of Tropical Disease, 6, 502-504. https://doi.org/10.1016/S2222-1808(16)61076-9

[57] Sabir, S., Akram, A., Raja, N.I., Mashwani, Z.R., Sohail, Sadaf, H.M., Hussain, M., Riaz, I., Ahmad, N. and Ahmed, E. (2016) A Probe into the Medicinal Potential of Viola canescens - A Threatened Medicinal Plant from Himalaya. Journal of Coastal Life Medicine, 4, 575-579. https://doi.org/10.12980/jclm.4.2016J6-41

[58] Iqbal, M., Raja, N.I., Asif, S., Ilyas, N., Hussain, M., Yasmeen, F., Ejaz, M., Sultan, M.A., Aslam, S. and Javed, H. (2016) In Vitro Study of Callogenesis and Regeneration Potential of Elite Wheat (Triticum aestivum L.) Cultivars. American Journal of Plant Sciences, 7, 2515-2526. https://doi.org/10.4236/ajps.2016.717219

[59] Iqbal, M., Bibi, Y., Raja, N.I., Ejaz, M., Hussain, M., et al. (2017) Review on Therapeutic and Pharmaceutically Important Medicinal Plant Asparagus officinalis L. Journal of Plant Biochemistry and Physiology, 5, 180. https://doi.org/10.4172/2329-9029.1000180

Submit or recommend next manuscript to SCIRP and we will provide best service for you:

Accepting pre-submission inquiries through Email, Facebook, LinkedIn, Twitter, etc. A wide selection of journals (inclusive of 9 subjects, more than 200 journals)

Providing 24-hour high-quality service

User-friendly online submission system

Fair and swift peer-review system

Efficient typesetting and proofreading procedure

Display of the result of downloads and visits, as well as the number of cited articles

Maximum dissemination of your research work

Submit your manuscript at: http://papersubmission.scirp.org/

Or contact ajps@scirp.org 